\title{
Study of surface morphology and inhibition efficiency of mild steel in simulated concrete pore solution by lactic acid- $\mathbf{Z n}^{2+}$ system
}

\author{
P.N. Devi, ${ }^{1}$ J. Sathiyabama ${ }^{1}$ and S. Rajendran ${ }^{1,2}$ \\ ${ }^{1} P G$ and Research Department of Chemistry, GTN Arts College, Dindigul-624005, India \\ ${ }^{2}$ Corrosion Research Centre, Department of Chemistry, St Antony's College of Arts \\ and Sciences for Women, Amala Annai Nagar, Thamaraipadi (Post),
}

Dindigul - 624 005, Tamilnadu, India

E-mail: susairajendran@gmail.com

\begin{abstract}
The inhibition efficiency (IE) of lactic acid- $\mathrm{Zn}^{2+}$ system in controlling corrosion of mild steel in simulated concrete pore solution (SCPS) prepared in well water in the absence and presence of $\mathrm{Zn}^{2+}$ has been investigated by weight loss study. The formulation consisting of $250 \mathrm{ppm}$ of lactic acid and $50 \mathrm{ppm}$ of $\mathrm{Zn}^{2+}$ provides $94 \%$ of inhibition efficiency. Inhibition was found to increase with an increasing concentration of lactic acid and $\mathrm{Zn}^{2+}$. Polarization resistance was measured by weight loss method, polarization study. The surface morphology has been investigated by SEM and AFM.
\end{abstract}

Keywords: concrete corrosion, simulated concrete pore solution, mild steel, lactic acid, well water.

Received: November 19, 2016. Published: December 27, $2016 . \quad$ doi: 10.17675/2305-6894-2017-6-1-2

\section{Introduction}

The corrosion of concrete steel reinforcement is a major issue that concerns not only the civil engineering industry but also other areas such as the nuclear industry. Due to the alkalinity of the interstitial solution $(\mathrm{pH} \mathrm{13})$, steel reinforcements remain passive. Long term exposure to environmental actions (chemical, biological and physical effects of the environment), causes deterioration of concrete and reinforcement. When considering the reliability of structures all type of actions should be taken into accounts. This holistic approach to the design and verification of structures shall be applied to all constructions especially civil engineering works, because of their larger ratio between the area exposed to the surrounding environment and cross-section dimensions as well as longer design life [1].

Metals are extracted from their ores by reduction process. When metals come in contact with the environment, especially oxygen and moisture, they deteriorate. This process, we call corrosion. Corrosion is the desire of pure metals to go back to its original state of ores. Corrosion is a natural, spontaneous and thermodynamically stable process. The process of corrosion can be controlled but it cannot be prevented. Carbon steel 
reinforcements in concrete structures are in passive conditions that they are protected by a thin oxide layer promoted by the concrete alkalinity. Corrosion can initiate only when passivity is destroyed. This occurs in two ways: carbonation of concrete, the reaction of atmospheric $\mathrm{CO}_{2}$ with cement paste, that lowers $\mathrm{pH}$ and causes general corrosion; the presence of chlorides at the steel surface in concentration higher than a critical threshold, generally considered in the range of $0.4-1 \%$ by a cement weight [2]. Among available methods, corrosion inhibitors seem to be attractive because of their low cost and easy handling, compared with other preventive methods. Inhibitors can be divided in two groups: admixed inhibitors, added to fresh concrete for new structures, and migrating inhibitors, which can penetrate into the hardened concrete and are usually proposed in repair systems. While admixed inhibitors are commercially available since 70's, migrating corrosion inhibitors for concrete structures were proposed in the last 15-20 years [3]. Nowadays, there are several admixtures available on the market: inorganic compounds based on nitrites, especially used as additives [4-8] and sodium monofluorophosphate used as migrating inhibitors [9,10], organic compounds based on mixtures of alkanolamines, amines or amino acids, or based on an emulsion of unsaturated fatty acid, proposed both as admixed and migrating inhibitor [11]. Other non commercial inhibitors, both inorganic and organic were studied: zinc oxide [12], molybdates and borates [13], stannates [14], carboxylate ions, quaternary ammonium salts and many other organic compounds [15]. The present work is undertaken:

1. To evaluate the inhibition efficiency and the corrosion resistance by weight loss method and electrochemical studies.

2. To study of the surface morphology by FTIR, scanning electron microscopy (SEM) and atomic force microscope (AFM).

\section{Experimental section}

\section{Preparation of simulated concrete pore solution (SCPS)}

Simulated concrete pore solution mainly consists of saturated $\mathrm{Ca}(\mathrm{OH})_{2}, \mathrm{KOH}$, and $\mathrm{NaOH}$ with the $\mathrm{pH} 13.5$ [16]. However in numerous studies of rebar corrosion, saturated $\mathrm{Ca}(\mathrm{OH})_{2}$ has been used a substitute for pore solution. Saturated calcium hydroxide solution is used in present study, as simulated concrete pore solution with the $\mathrm{pH} 12.5$.

\section{Preparation of the specimens}

Metal specimens of the dimensions $1 \times 4 \times 0.2 \mathrm{~cm}$ were polished to a mirror finish and degreased with acetone. Then they were used for the weight-loss method and surface examination studies. The environment chosen is well water and the physico-chemical parameters of well water are given in Table 1. 
Table 1. Physicochemical parameters of well water.

\begin{tabular}{cc}
\hline Parameters & Value \\
\hline pH & 8.38 \\
Conductivity & $1770 \mu \Omega^{-1} \mathrm{~cm}^{-1}$ \\
Chloride & $665 \mathrm{ppm}$ \\
Sulphate & $214 \mathrm{ppm}$ \\
TDS & $1100 \mathrm{ppm}$ \\
Total hardness & $402 \mathrm{ppm}$ \\
Total alkalinity & $390 \mathrm{ppm}$ \\
Magnesium & $83 \mathrm{ppm}$ \\
Potassium & $55 \mathrm{ppm}$ \\
Sodium & $172 \mathrm{ppm}$ \\
Calcium & $88 \mathrm{ppm}$ \\
\hline
\end{tabular}

\section{Determination of Corrosion Rate}

The weighed specimens in triplicate were suspended by means of glass hooks in $100 \mathrm{ml}$ SCPS prepared in well water containing various concentration of lactic acid in the presence and absence of $\mathrm{Zn}^{2+}$ for one day. The specimen were taken out, washed in running water, dried, and weighed. From the change in weights of the specimens, corrosion rates were calculated using the following relationship:

$C R=\left[(\right.$ Weight loss in $\mathrm{mg}) /\left(\right.$ Area of specimens in $\mathrm{dm}^{2} \times$ Immersion period in days $\left.)\right]$ mdd (1)

Corrosion inhibition efficiency (IE, \%) was then calculated using the equation:

$$
I E=100\left[1-\left(W_{2} / W_{1}\right)\right] \%
$$

Where, $W_{1}=$ corrosion rate in the absence of the inhibitors, and $W_{2}=$ corrosion rate in the presence of the inhibitors.

\section{Potentiodynamic Polarization}

Polarization studies were carried out in a CHI - Electrochemical workstation with impedance, Model 660A. A three-electrode cell assembly was used. The three electrode assembly is shown in Figure 1. The working electrode was mild steel. A saturated calomel electrode (SCE) was the reference electrode and platinum was the counter electrode. From the polarization study, corrosion parameters such as corrosion potential $\left(E_{\text {corr }}\right)$, corrosion current $\left(I_{\text {corr }}\right)$ and Tafel slopes (anodic $=b_{\mathrm{a}}$ and cathodic $=b_{\mathrm{c}}$ ) and Linear polarization resistance $(\mathrm{LPR})$ were calculated. The scan rate $(\mathrm{V} / \mathrm{s})$ was 0.01 . Hold time at $\left(E_{\mathrm{fcs}}\right)$ was zero and quit time (s) was two. 


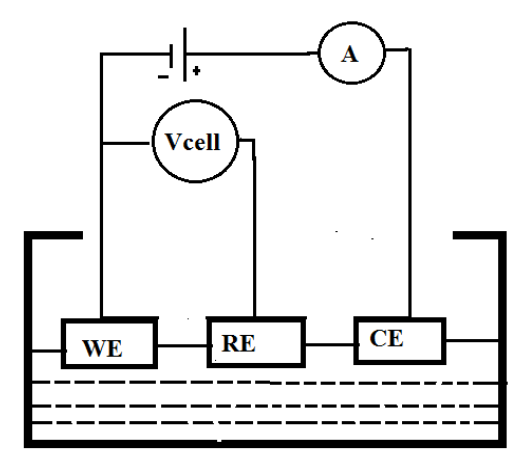

Figure 1. Circuit diagram of three-electrode cell assembly.

\section{Fourier Transform Infrared Spectra}

These spectra were recorded in a Perkin-Elmer 1600 spectrometer using $\mathrm{KBr}$ pellets. The spectrum of the protective film was recorded by carefully removing the film, mixing it with $\mathrm{KBr}$ and making the pellet.

\section{Scanning Electron Microscopic Studies (SEM)}

The carbon steel immersed in blank solution and in the inhibitor solution for a period of one day was removed, rinsed with double-distilled water, dried, and observed in a scanning electron microscope to examine the surface morphology. The surface morphology measurements of carbon steel were examined using JEOL MODEL6390 computercontrolled scanning electron microscope.

\section{Atomic Force of Microscopy}

The mild steel specimens were immersed in blank and in the inhibitor solution for a period of one day. The specimens were removed, rinsed with double distilled water, dried and subjected to the surface examination. Atomic force microscopy (Veeco Innova model) was used to observe the samples surface in tapping model, using cantilever with linear tips. The scanning area in the images was $50 \mu \mathrm{m} \times 50 \mu \mathrm{m}$ and the scan rate was $1 \mu \mathrm{m} / \mathrm{s}$.

\section{Results and Discussion}

\section{Analysis of Weight loss Study}

Corrosion rates of carbon steel immersed in SCPS prepared in well water in the absence and presence of inhibitors (lactic acid and $\mathrm{Zn}^{2+}$ system) were calculated. The calculated corrosion inhibition efficiency $(I E)$ and corrosion rates $(C R)$ of lactic acid in controlling corrosion of SCPS in well water, for a period of one day in absence and presence of zinc ion are given in Table 2 and represented in Figure 2. It is observed from the Table 2 that lactic acid is a good inhibitor. The $I E$ is found to be enhanced in the presence of $\mathrm{Zn}^{2+}$ ion. Lactic acid alone shows some inhibition efficiencies. The formulation consisting of $250 \mathrm{ppm}$ of lactic acid and $50 \mathrm{ppm}$ of $\mathrm{Zn}^{2+}$ shows $94 \%$ of inhibition efficiency. Weight loss 
study reveals that lactic acid and $\mathrm{Zn}^{2+}$ individually showed some $I E$, but exhibited better $I E$ when applied in combination. This suggests that LA and $\mathrm{Zn}^{2+}$ exhibit synergistic behaviour [17-20].

Table 2. Corrosion rates $(C R)$ of mild steel immersed in simulated concrete pore solution (SCPS) prepared in well water in the presence and absence of lactic acid $\mathrm{Zn}^{2+}$ in the inhibition efficiency (IE) obtained by weight loss method.

\begin{tabular}{ccccccc}
\hline \multirow{2}{*}{$\begin{array}{c}\text { Lactic acid } \\
\mathbf{p p m}\end{array}$} & \multicolumn{2}{c}{$\mathbf{Z n}^{2+}(\mathbf{0} \mathbf{~ p p m})$} & \multicolumn{2}{c}{$\mathbf{Z n}^{2+}(\mathbf{2 5} \mathbf{~ p p m})$} & \multicolumn{2}{c}{$\mathbf{Z n}^{\mathbf{2 +}}(\mathbf{5 0} \mathbf{~ p p m})$} \\
\cline { 2 - 6 } & $\boldsymbol{I E} \%$ & $\boldsymbol{C R}, \mathbf{m d d}$ & $\boldsymbol{I E} \%$ & $\boldsymbol{C R}, \mathbf{m d d}$ & $\boldsymbol{I E} \%$ & $\boldsymbol{C R}$, mdd \\
\hline 0 & - & 16 & 17 & 13.2 & 21 & 14.0 \\
50 & 19 & 12.96 & 31 & 11.04 & 38 & 9.92 \\
100 & 25 & 12.00 & 38 & 9.92 & 50 & 8.00 \\
150 & 36 & 10.24 & 40 & 9.60 & 65 & 5.60 \\
200 & 44 & 8.96 & 50 & 8.00 & 81 & 3.40 \\
250 & 63 & 5.92 & 75 & 4.00 & 94 & 0.96 \\
\hline
\end{tabular}

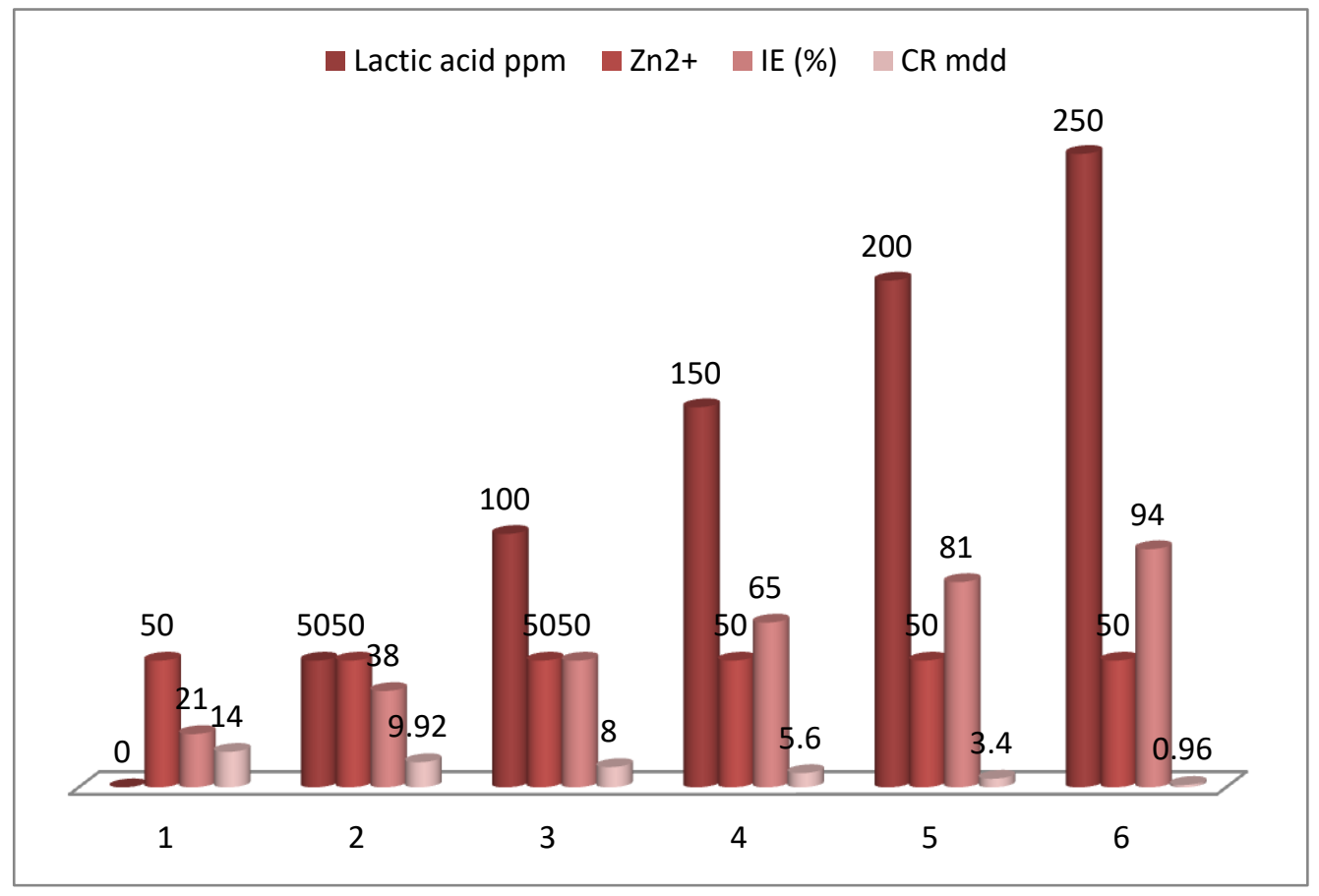

Figure 2. Corrosion rates $(C R)$ and inhibition efficiency $(I E)$ of lactic acid- $\mathrm{Zn}^{2+}$ system in the corrosion of mild steel immersed in simulated concrete pore solution (SCPS) prepared in well water. 


\section{Analysis of Polarization Curves}

When mild steel is immersed in simulated concrete pore solution prepared in well water the corrosion potential was $-842 \mathrm{mV}$ vs SCE (Figure 3). When lactic acid (250 ppm) and $\mathrm{Zn}^{2+}(50 \mathrm{ppm})$ are added to the above system the corrosion potential shifted to the anodic side $-774 \mathrm{mV}$ vs SCE; that is noble side. This indicates that the $\mathrm{LA}-\mathrm{Zn}^{2+}$ system controls anodic reaction predominantly. It is inferred that a passive film is formed on the metal surface in presence of inhibitor. The shifting of corrosion potential towards anodic side in presence of inhibitors has been reported by several researchers [21-24].

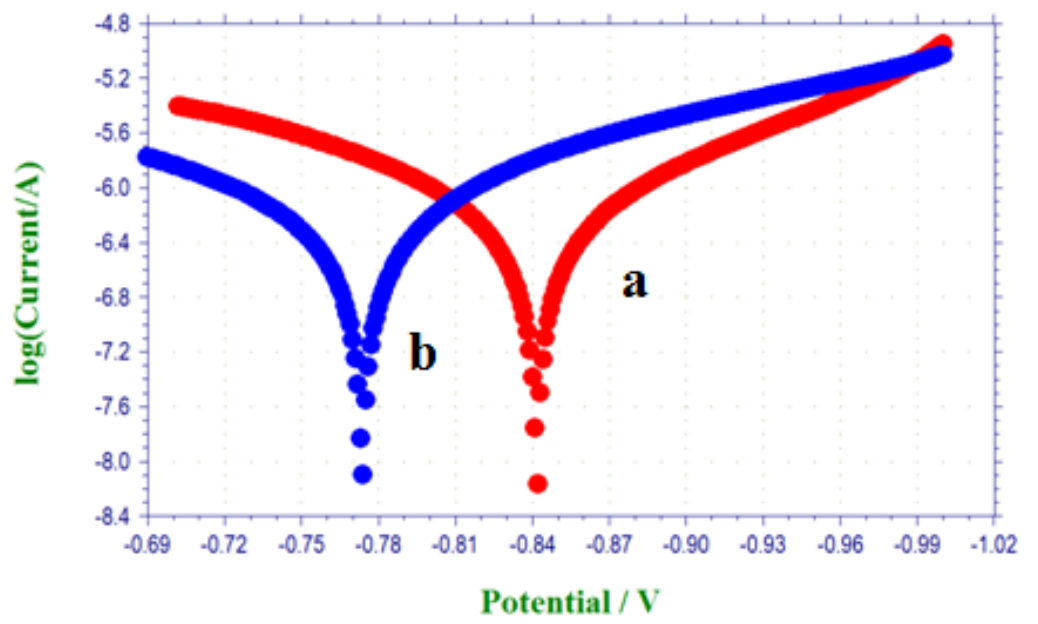

Figure 3. Polarization curves of mild steel immersed in various test solution: a) SCPS ; b) lactic acid $250 \mathrm{ppm}+\mathrm{Zn}^{2+} 50 \mathrm{ppm}$.

Further, the LPR value increases from $41473 \mathrm{Ohm} \mathrm{cm}^{2}$ to $47099 \mathrm{Ohm} \mathrm{cm}^{2}$; the corrosion current decreases from $7.237 \cdot 10^{-7} \mathrm{~A} / \mathrm{cm}^{2}$ to $5.768 \cdot 10^{-7} \mathrm{~A} / \mathrm{cm}^{2}$. When a passive film formed on mild steel surface, in presence of inhibitor system the electron transfer from the metal surface towards the bulk of the solution is difficult and prevented. So rate of corrosion decreases and hence corrosion current decreases in presence of inhibitor system.

Table 3. Corrosion parameters of mild steel immersed in SCPS prepared in well water in the absence and presence of inhibitor system obtained from Potentiodynamic Polarization Study.

\begin{tabular}{cccccc}
\hline System & $\begin{array}{c}\boldsymbol{E}_{\text {corr }} \\
\mathbf{m V} \boldsymbol{v s} \mathbf{S C E}\end{array}$ & $\begin{array}{c}\boldsymbol{b}_{\mathbf{c}} \\
\mathbf{m V} / \mathbf{d e c a d e}\end{array}$ & $\begin{array}{c}\boldsymbol{b}_{\mathbf{a}} \\
\mathbf{m V} / \mathbf{d e c a d e}\end{array}$ & $\begin{array}{c}\mathbf{L P R} \\
\mathbf{O h m} \mathbf{~ c m}^{\mathbf{2}}\end{array}$ & $\begin{array}{c}\boldsymbol{I}_{\text {corr }} \\
\mathbf{A} / \mathbf{c m}^{\mathbf{2}}\end{array}$ \\
\hline SCPS & -842 & 131 & 145 & 41473 & $7.237 \cdot 10^{-7}$ \\
$\begin{array}{c}\text { SCPS }+ \text { lactic acid 250 ppm + } \\
\mathrm{Zn}^{2+} 50 \mathrm{ppm}\end{array}$ & -774 & 171 & 213 & 47099 & $5.768 \cdot 10^{-7}$ \\
\hline
\end{tabular}




\section{Analysis of AC Impedance spectra}

AC impedance spectra (electrochemical impedance spectra) have been used to confirm the formation of protective film on the metal surface. If a protective film is formed on the metal surface, charge transfer resistance decreases and the impedance log $(z / \mathrm{ohm})$ value increases $[25,26]$. The AC impedance spectra of mild steel immersed in SCPS prepared in well water in the absence and presence of inhibitors $\left(\mathrm{LA}-\mathrm{Zn}^{2+}\right)$ are shown in Figure 4 (Nyquist plots) and Figures 5a and 5b (Bode plots). The AC impedance parameters namely charge transfer resistance $\left(R_{\mathrm{t}}\right)$ and double layer capacitance $\left(C_{\mathrm{dl}}\right)$ derived from Nyquist plots are given in Table 4 . The impedance $\log (z / \mathrm{ohm})$ values derived from Bode plots are also given in Table 4.

Table 4. Corrosion parameters of mild steel immersed in SCPS prepared in well water in the absence and presence of inhibitor system obtained from AC impedance spectra.

\begin{tabular}{cccc}
\hline & \multicolumn{2}{c}{ Nyquist plot } & Bode plot \\
\cline { 2 - 4 } System & $\boldsymbol{R}_{\mathbf{t}}, \mathbf{O} \mathbf{~} \mathbf{~ c m}^{2}$ & $\boldsymbol{C}_{\mathbf{d l}}, \mathbf{F} / \mathbf{c m}^{2}$ & $\begin{array}{c}\text { Impedance value } \\
\mathbf{l o g}(\boldsymbol{z} / \mathbf{O h m})\end{array}$ \\
\hline $\begin{array}{c}\text { SCPS } \\
\text { SCPS }+ \text { lactic acid } 250 \mathrm{ppm}+ \\
+\mathrm{Zn}^{2+} 25 \mathrm{ppm}\end{array}$ & 566 & $9.013 \cdot 10^{-9}$ & 2.86 \\
\hline
\end{tabular}

It is observed that when the inhibitors lactic acid $(250 \mathrm{ppm})+\mathrm{Zn}^{2+}(50 \mathrm{ppm})$ are added to SCPS, the charge transfer resistance $\left(R_{\mathrm{t}}\right)$ increases from $566 \mathrm{Ohm} \mathrm{cm}{ }^{2}$ to1385 $\mathrm{Ohm} \mathrm{\textrm {cm } ^ { 2 }}$. The $C_{\mathrm{dl}}$ value decreases from $9.013 \cdot 10^{-9} \mathrm{~F} / \mathrm{cm}^{2}$ to $3.683 \cdot 10^{-9} \mathrm{~F} / \mathrm{cm}^{2}$. The impedance values $[\log (z / \mathrm{ohm})]$ increases from 2.86 to 3.28 . These results lead to the conclusion that a protective film is formed on the metal surface.

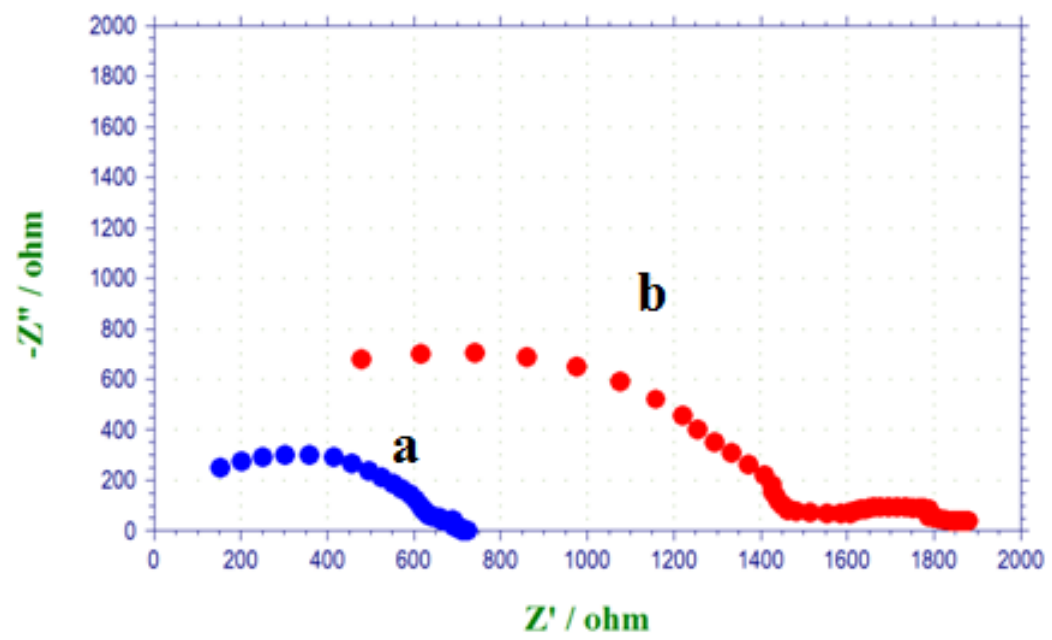

Figure 4. AC Impendence curves of mild steel immersed in various test solution (Nyquist plots ): a) SCPS; b) SCPS + lactic acid $250 \mathrm{ppm}+\mathrm{Zn}^{2+} 50 \mathrm{ppm}$. 

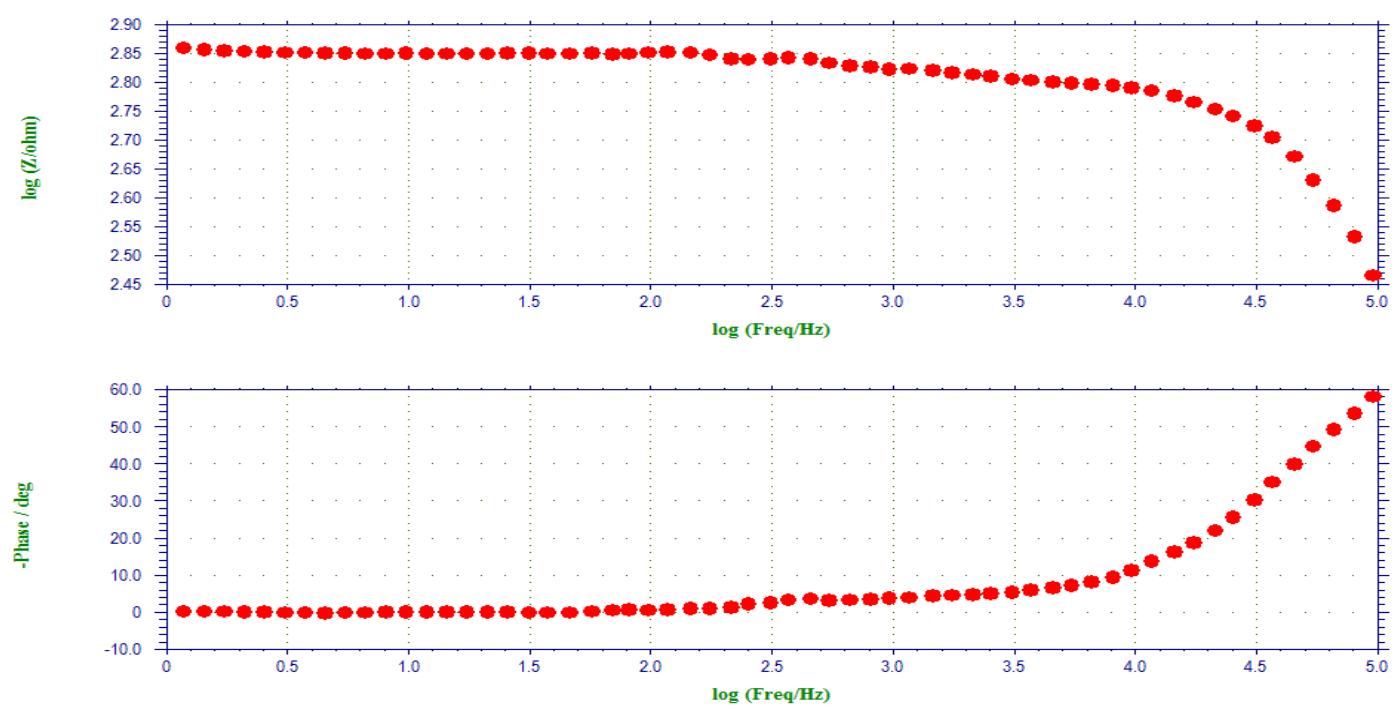

Figure 5(a). AC impendance spectra of mild steel immersed in SCPS (Bode plots).
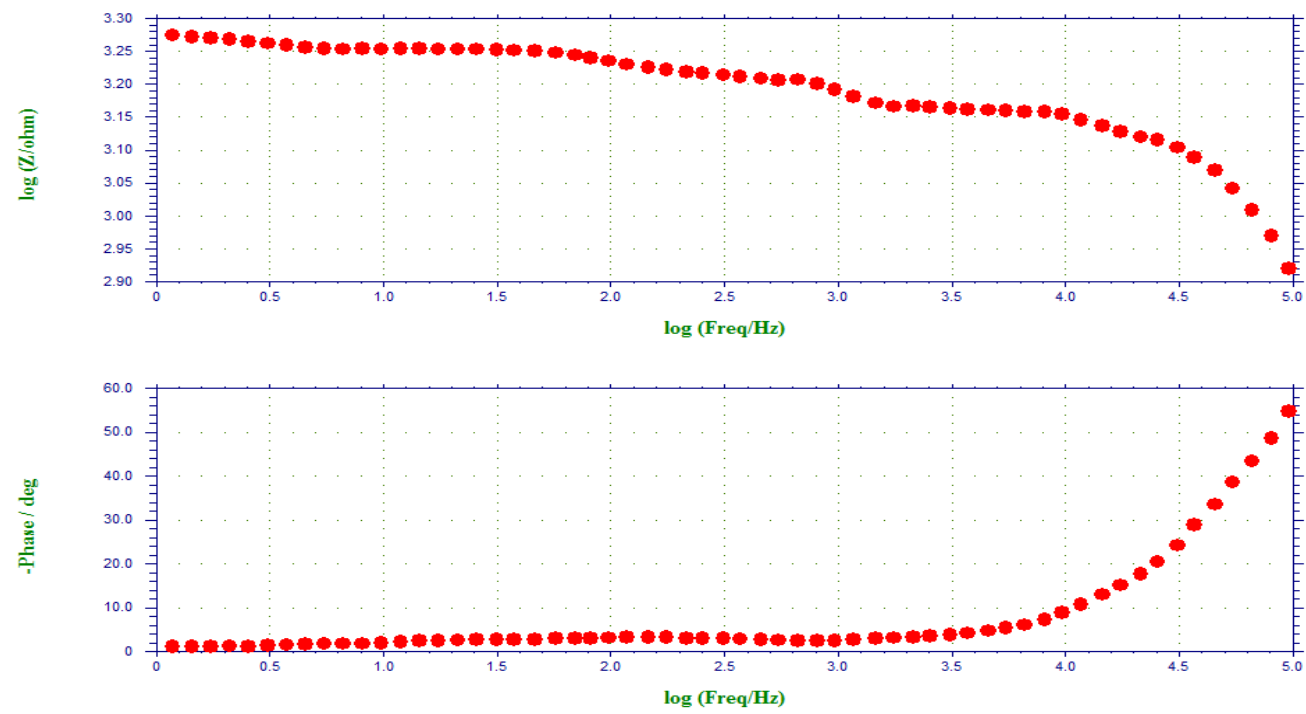

Figure 5(b). AC impendance spectrum of mild steel immersed in SCPS + 250 ppm lactic acid + 25 ppm $\mathrm{Zn}^{2+}$ system (Bode plots).

\section{Analysis of FTIR spectra}

The FTIR spectra were used to analyze the inhibitor film formed on mild steel. The FTIR spectrum of the pure lactic acid (Figure 6a) is compared with the FTIR spectrum of film formed on the metal surface after immersion in SCPS prepared in well water containing $250 \mathrm{ppm}$ of lactic acid and $50 \mathrm{ppm}$ of $\mathrm{Zn}^{2+}$ (Fig. 6b). The results showed that the $\mathrm{OH}$ stretching frequency of pure lactic acid appears at $3464 \mathrm{~cm}^{-1}$ where as in the SCPS containing $250 \mathrm{ppm}$ of lactic acid and $50 \mathrm{ppm}$ of $\mathrm{Zn}^{2+}$ system, the stretching frequency has shifted from $3464 \mathrm{~cm}^{-1}$ to $3358 \mathrm{~cm}^{-1}$. In case of $\mathrm{C}=\mathrm{O}$, the stretching frequency which appeared at $1733 \mathrm{~cm}^{-1}$ for lactic acid has disappeared for the SCPS system containing $250 \mathrm{ppm}$ of lactic acid and $50 \mathrm{ppm}$ of $\mathrm{Zn}^{2+}$ system. This confirms that the oxygen atom of 
carboxyl group has coordinated with $\mathrm{Fe}^{2+}$ resulting in the formation of $\mathrm{Fe}^{2+}$-lactic acid complex formed on the metal surface. And also, the peak appearing at 1435, 1024 and $693 \mathrm{~cm}^{-1}$ confirmed the presence of calcium carbonate, calcium oxide and calcium hydroxide formed on the metal surface $[27,28]$.

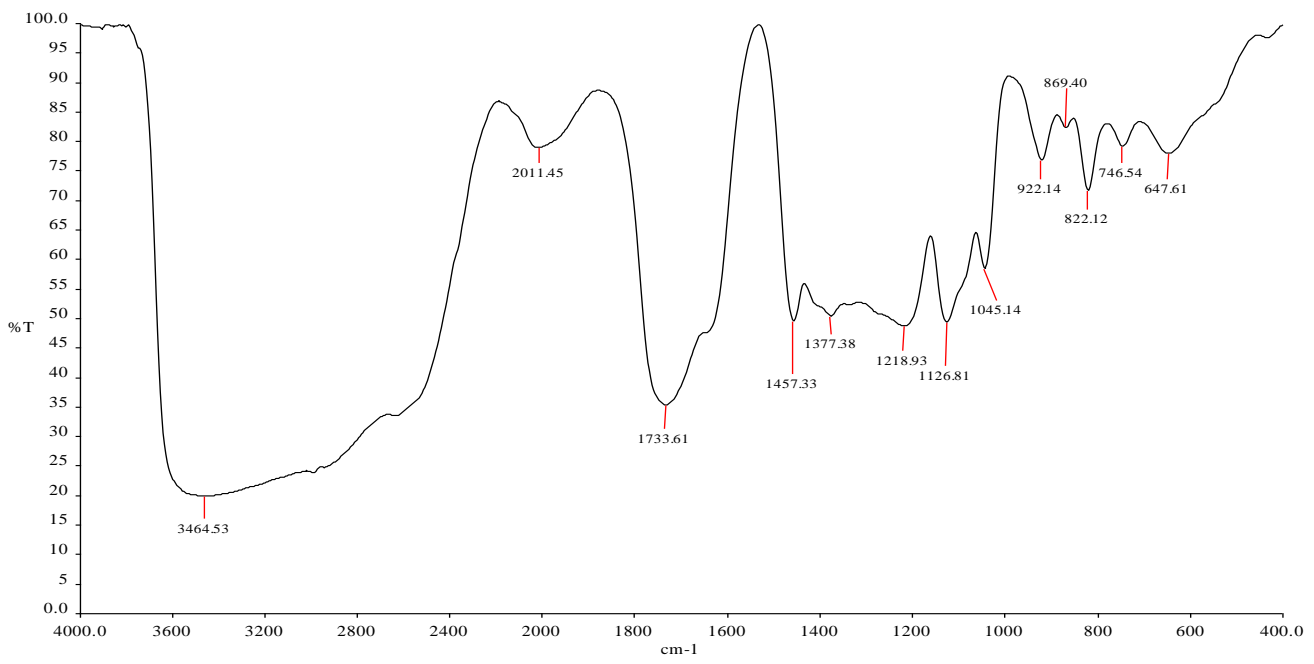

Figure 6(a). FTIR spectrum of pure lactic acid.

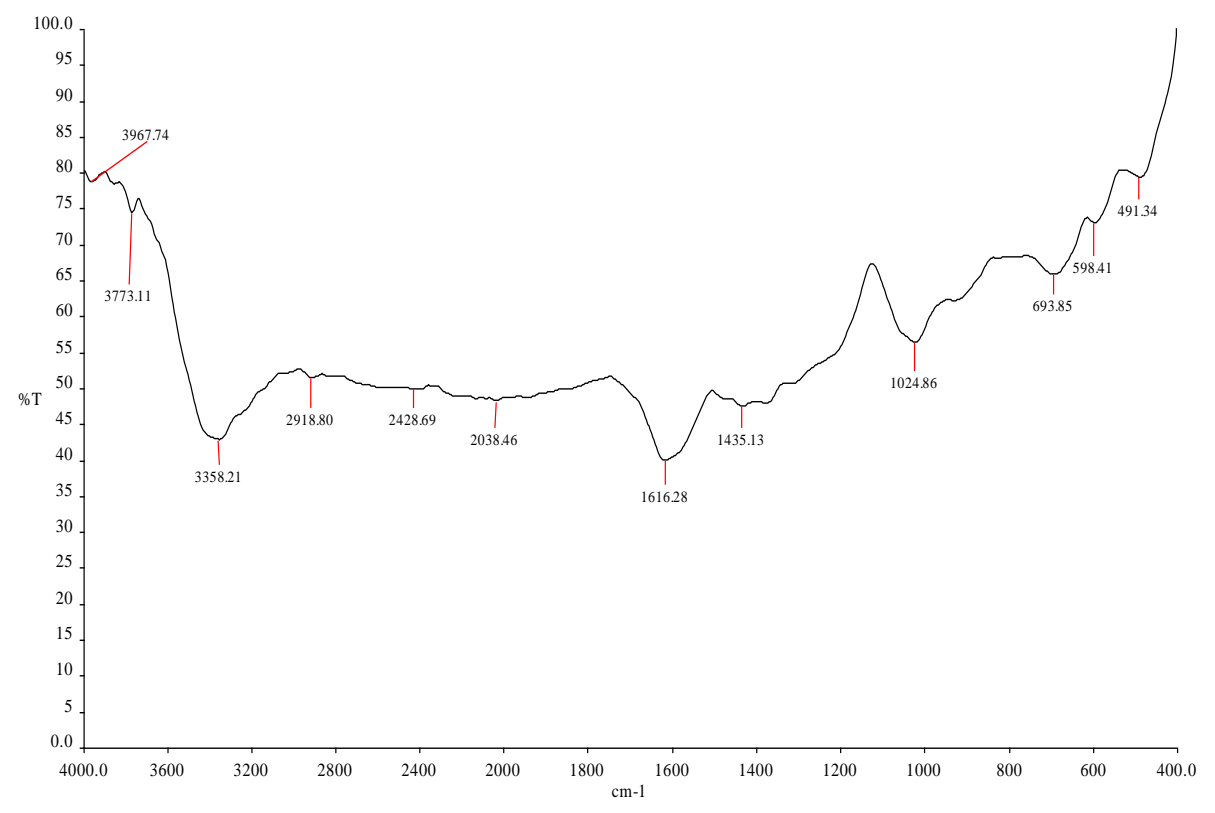

Figure 6(b). FTIR spectrum of inhibitor film formed on the mild steel after immersion in SCPS prepared in well water containing of $250 \mathrm{ppm}$ lactic acid and $50 \mathrm{ppm}$ of $\mathrm{Zn}^{2+}$. 


\section{Scanning Electron Microscopy( SEM)}

Surface morphology of mild steel was studied by scanning electron microscopy after $24 \mathrm{~h}$ immersion in SCPS before and after addition of inhibitor. Figure 7(a) represent the micrograph obtained of polished steel without being exposed to the corrosive environment while Figure 7(b) showed strongly damaged steel surface due to the formation of corrosion products after immersion in SCPS. SEM images of steel surface after immersion in $250 \mathrm{ppm}$ lactic acid and $50 \mathrm{ppm} \mathrm{Zn}^{2+}$ are shown in Figure 7(c).

The SEM micrograph $(\times 1000)$ of Figure 7 (a) shows the smooth surface of mild steel without any corrosion product or inhibitor complex on the metal surface. Inspection of Figure 7(b) reveals that the mild steel immersed in SCPS shows an aggressive attack of the corroding medium on the steel surface. In contrast, in the presence of $250 \mathrm{ppm}$ lactic acid and $50 \mathrm{ppm} \mathrm{Zn}^{2+}$ the mild steel surface coverage increses which in turn results in the formation of insoluble complex on the metal surface ( $\mathrm{LA}+\mathrm{Zn}$ inhibitor complex) [30-33].

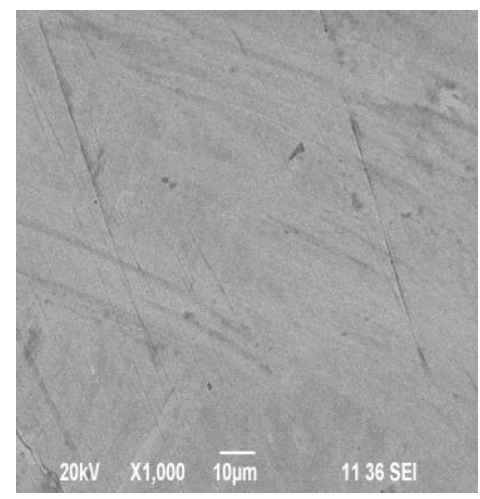

$\mathrm{a}$

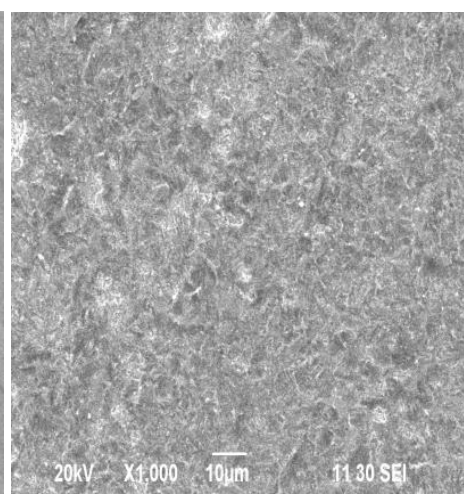

b

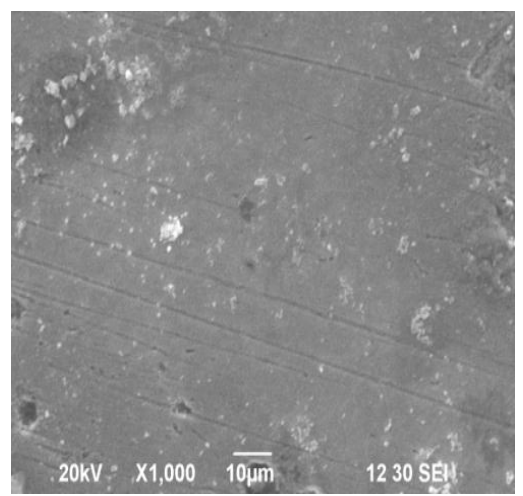

c

Figure 7. SEM micrographs of (a) mild steel; magnification $\times 1000$; (b) mild steel immersed in SCPS prepared in well water; magnification $\times 1000$; (c) mild steel immersed in SCPS prepared in well water containing LA $(250 \mathrm{ppm})+\mathrm{Zn}^{2+}(50 \mathrm{ppm})$; magnification $\times 1000$.

\section{Atomic Force Microscopy Characterization}

Atomic Force Microscopy (AFM Analysis) provides images with atomic or near-atomicresolution surface topography, capable of quantifying surface roughness of samples down to the angstrom-scale. Atomic force microscopy (AFM) or scanning force microscopy (SFM) is a very higher resolution type of scanning probe microscopy, with demonstrated resolution on the order of fractions of a nanometer, more than 1000 times better than the optical diffraction limit [21]. The three dimensional (3D) AFM morphologies and the AFM cross-sectional profile for polished carbon steel surface (reference sample), carbon steel surface immersed in SCPS (blank sample) and carbon steel surface immersed in SCPS containing the formulation of $250 \mathrm{ppm}$ of $\mathrm{LA}$ and $50 \mathrm{ppm}$ of $\mathrm{Zn}^{2+}$ are shown as Figure 8 images $(\mathrm{a}, \mathrm{d}),(\mathrm{b}, \mathrm{e}),(\mathrm{c}, \mathrm{f})$ respectively $[34,35]$. 

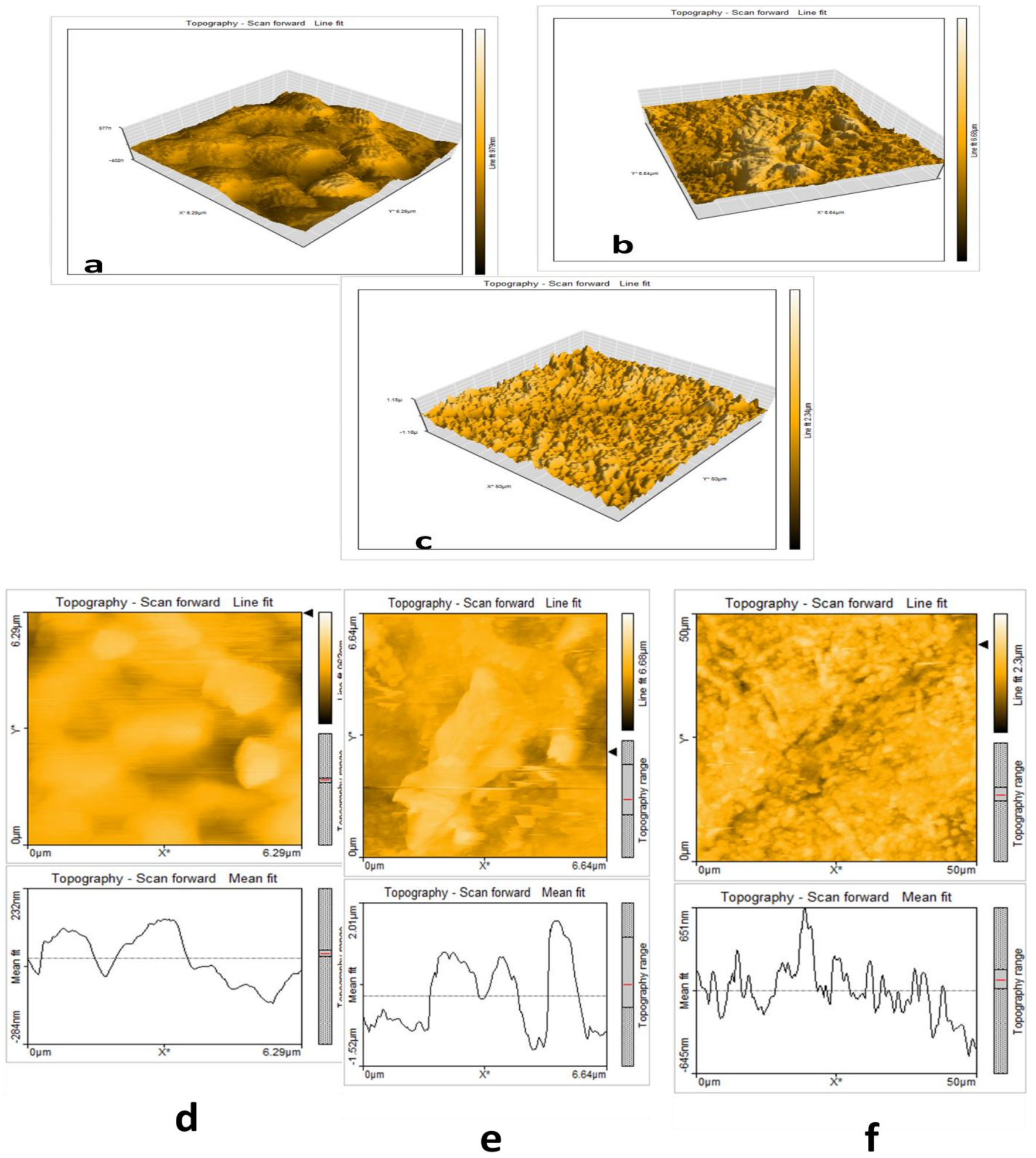

Figure 8. $(a, b, c)$. Three dimensional AFM images of the surface of: a) As polished carbon steel (control); b) carbon steel immersed in SCPS (blank); c) carbon steel immersed in SCPS containing LA $(250 \mathrm{ppm})+\mathrm{Zn}^{2+}(50 \mathrm{ppm}) ;(\mathrm{d}, \mathrm{e}, \mathrm{f})$. AFM cross-sectional images of the surface of: d) as polished carbon steel (control); e) carbon steel immersed in SCPS (blank); f) carbon steel immersed in SCPS containing LA (250 ppm) $+\mathrm{Zn}^{2+}(50 \mathrm{ppm})$. 
Root-mean-square roughness, average roughness and peak-to-valley value AFM image analysis was performed to obtain the average roughness, $R_{\mathrm{a}}$ (the average deviation of all points roughness profile from a mean line over the evaluation length), root-meansquare roughness, $R_{\mathrm{q}}$ (the average of the measured height deviations taken within the evaluation length and measured from the mean line) and the maximum peak-to-valley ( $\mathrm{P}-$ $\mathrm{V})$ height values (largest single peak-to-valley height in five adjoining sampling heights). Table 5 is a summary of $\left(R_{\mathrm{q}}\right),\left(R_{\mathrm{a}}\right),(\mathrm{P}-\mathrm{V})$ values for carbon steel surface immersed in different environments.

Table 5. AFM data for carbon steel surface immersed in inhibited and uninhibited environment.

\begin{tabular}{cccc}
\hline Samples & $\begin{array}{c}\text { RMS }\left(\mathbf{R}_{\mathbf{q}}\right) \\
\text { Roughness }(\mathbf{n m})\end{array}$ & $\begin{array}{c}\text { Average }\left(\mathbf{R}_{\mathbf{a}}\right) \\
\text { Roughness }(\mathbf{n m})\end{array}$ & $\begin{array}{c}\text { Maximum peak-to- } \\
\text { peak height }(\mathbf{n m})\end{array}$ \\
\hline Polished mild steel (Control) & 3.53 & 4.36 & 5.89 \\
Mild steel immersed in SCPS & 87.90 & 264.86 & 303.90 \\
$\begin{array}{c}\text { Mild steel immersed in SCPS + } \\
\text { lactic acid 250 ppm + } \\
\mathrm{Zn}^{2+} 50 \mathrm{ppm}\end{array}$ & 35.52 & 41.14 & 93.45 \\
\hline
\end{tabular}

Figure 8 (a, d) displays the surface topography of un-corroded metal surface. The value of $R_{\mathrm{q}}, R_{\mathrm{a}}$ and $\mathrm{P}-\mathrm{V}$ height for the polished carbon steel surface (reference sample) are $3.53 \mathrm{~nm}, 4.36 \mathrm{~nm}$ and $5.89 \mathrm{~nm}$ respectively. The slight roughness observed on the polished carbon steel surface is due to atmospheric corrosion. Figure $8(\mathrm{~b}, \mathrm{e})$ displays the corroded metal surface with few pits in the absence of the inhibitor immersed in SCPS. The $R_{\mathrm{q}}, R_{\mathrm{a}}$, $\mathrm{P}-\mathrm{V}$ height values for the carbon steel surface are $87.90 \mathrm{~nm}, 264.86 \mathrm{~nm}$ and $303.90 \mathrm{~nm}$ respectively. These data suggests that carbon steel surface immersed in SCPS has a greater surface roughness than the polished metal surface, which shows that the unprotected carbon steel surface is rougher and was due to the corrosion of the carbon steel in dam water environment. Figure 8(c, f) displays the steel surface after immersion in sea water containing $250 \mathrm{ppm}$ of LA and $50 \mathrm{ppm}$ of $\mathrm{Zn}^{2+}$. The $R_{\mathrm{q}}, R_{\mathrm{a}}, \mathrm{P}-\mathrm{V}$ height values for the carbon steel surface are $135.52 \mathrm{~nm}, 41.14 \mathrm{~nm}$ and $93.45 \mathrm{~nm}$ respectively. The $R_{\mathrm{q}}, R_{\mathrm{a}}, \mathrm{P}-\mathrm{V}$ height values are considerably less in the inhibited environment compared to the uninhibited environment. These parameters confirm that the surface is smoother. The smoothness of the surface is due to the formation of a compact protective film of $\mathrm{Fe}^{2+}-\mathrm{LA}$ complex and $\mathrm{Zn}(\mathrm{OH})_{2}$ on the metal surface there by inhibiting the corrosion of carbon steel $[34,35]$.

\section{Acknowledgement}

The authors are thankful to their respective management for their help and encouragement. 


\section{Conclusion}

The present study leads to the following conclusions:

i. The formulation consisting of $250 \mathrm{ppm}$ of lactic acid and $50 \mathrm{ppm}$ of $\mathrm{Zn}^{2+}$ offers $94 \% \mathrm{IE}$ to mild steel immersed in simulated concrete pore solution prepared in well water.

ii. Polarization study reveals that lactic acid system controls the anodic reaction predominantly.

iii. AC impedance spectra reveal that the formation of protective film on the metal surface.

iv. FTIR spectra reveal that the inhibitive film consists of $\mathrm{Fe}^{2+}$-lactic acid complex, calcium carbonate, calcium oxide and calcium hydroxide.

v. SEM and AFM images confirmed the protective film formed on the metal surface was smooth and stable.

\section{References}

1. L. Bertonoli, B. Elsener, P. Pedeferi and R. Polder, Corrosion of Steel in Concrete: Prevention, Diagnosis, Repair, Wiley, Weinhein, 2004.

2. C.L. Page, Nature and Properties of Concrete in Relation to Reinforcement Corrosion. Corrosion of steel in Concrete, Aachen, 1992.

3. B. Elsener, Corrosion Inhibitors for steel in Concrete - State of the Art Report, EFC Publications, Vol. 35, 2001.

4. N.S. Berke, Mater. Perform., 1989, 23, no. 10, 41.

5. N.S. Berke and T.G. Weil, World-wide Review of Corrosion Inhibitors in Concrete; Advances in Concrete Technology, CANMET, 1992, Athen, Greece, pp. 899-924.

6. R. Cigna, G. Familiari, F. Gianetti and E. Proverbio, International Conference on Corrosion and Corrosion Protection of steel in Concrete, 1994, Sheffild, 878.

7. I. Callander and A. Gianetti, A review on the use of C.N corrosion inhibitor to improve the durability of reinforced concrete, The 2nd Annual Middle East Protection and Rehabilitation of Reinforced Concrete Conference, Dubai, 1996, 1-1.

8. N.S. Berke and M.C. Hicks, Cem. Concr. Compos., 2004, 26, 191.

9. C. Andrade, C. Alons, M. Acha and B. Malric, Cem. Concr. Compos, 1996, 26, 191.

10. V.T. Nagla, C.L. Page and M.M. Page, Corros. Sci., 2003, 45, 1523.

11. D. Bejegovic, B. Miksic, Mater. Perform, 1999, 11, 52.

12. O.T. de Rincon Preez, E. Paredes, Y. Caldera, C. Urdaneta and C. Sandoval, Cem. Concr. Compos, 2002, 24, 79.

13. K.K. Sagoe-Crentsil, V.T. Yilmaz and F.P. Glasser, Adv. Cem. Res., 1996, 4, 91.

14. K.K. Sagoe-Crentsil, F.P. Glasser and V.T. Yilmaz, Cem. Concr. Compos., 1994, 24, 313.

15. V. Saraswathy, S. Muralidharan, R.M. Kalyanasundaram, S. Thangavel and S. Srinivasan, Cem. Concr. Compos., 2001, 31, 789.

16. R. Liu, L. Jiang, J. Xu, C. Xiong and Z. Song, Constr. Build. Mater., 2014, 56, 16.

17. M. Manivannan and S. Rajendran, Int. J. Eng. Sci. Technol., 2011, 3, 19. 
18. V. Johnsirani, J. Sathiyabama, S. Rajendran, T. Shanthi, T.S. Muthumegala and A. Krishnaveni, Bulg. Chem. Commun., 2012, 44, 41.

19. R. Epshiba, A.P.P. Regis and S. Rajendran, Int. J. Nano Corr. Sci. Eng., 2014, 1, no. 1, 1 .

20. N. Kavitha and P. Manjula, Int. J. Nano Corr. Sci. Eng., 2014, 1, no. 1, 31.

21. R. Nagalakshmi, L. Nagarajan, R.J. Rathish, S.S. Prabha, N. Vijaya, J. Jeyasundari and S. Rajendran, Int. J. Nano Corr. Sci. Eng., 2014, 1, no. 1, 39.

22. J. A. Thangakani, S. Rajendran, J. Sathiabam, R.M. Joany, R.J. Rathis and S.S. Prabha, Int. J. Nano Corr. Sci. Eng., 2014, 1, no. 1, 50.

23. A. Nithya, P. Shanthy, N. Vijaya, R.J. Rathish, S.S. Prabha, R.M. Joany and S. Rajendran, Int. J. Nano Corr. Sci. Eng., 2015, 2, no. 1, 1.

24. T. Gowrani, P. Manjula, C.N. Baby, K.N. Manonmani, R. Sudha and T. Vennila, Int. J. Nano Corr. Sci. Eng., 2015, 2, no. 1, 12.

27. K. Namita, K. Johar, R. Bhrara, R. Epshiba and G. Singh, Int. J. Nano Corr. Sci. Eng., 2015, 2, no. 1, 22.

25. A.C.C. Mary, S. Rajendran, H. Al-Hashem, R.J. Rathish, T. Umasankareswari and J. Jeyasundari, Int. J. Nano Corr. Sci. Eng., 2015, 2, no. 1, 42.

26. V. Johnsirani, S. Rajendran, A. C.C. Mary, R.J. Rathish, T. Umasankareswari and J. Jeyasundari, Int. J. Nano Corr. Sci. Eng., 2015, 2, no. 3, 22.

27. P.N. Devi, J. Sathiyabama, S. Rajendran, R. J. Rathish and S.S. Prabha, Int. J. Nano Corr. Sci. Eng., 2015, 2, no. 4, 1.

28. T. Shanthi and S. Rajendran, J. Chem. Biol. Phys. Sci., 2013, 3, no. 4, 2550.

29. P.N. Devi, J. Sathiyabama, S. Rajendran, R.J. Rathish and S.S. Prabha, Int. J. Nano Corr. Sci. Eng., 2015, 2, no. 3, 1.

30. D.B. Hmamou, R. Salghi, A. Zarrouk, M. Messali, H. Zarrok, M. Errami, B. Hammouti, Lh. Bazzi and A. Chakir, Der Pharma Chemica, 2012, 4, no. 4, 1496.

31. M. Sangeetha, S. Rajendran, J. Sathiyabama, T. Umasankareswari, A. Krishnaveni and R.M. Joany, Int. J. Nano Corr. Sci. Eng., 2015, 2, no. 3, 14.

32. P.N. Devi, J. Sathiyabama, S. Rajendran, R.J. Rathish and D. Renita, Int. J. Nano Corr. Sci. Eng., 2015, 2, no.5, 347.

33. A.K. Singh and M.A. Quraishi, Corros. Sci., 2011, 53, no. 4, 1288.

34. M. Sangeetha, S. Rajendran, J. Sathiyabama, A. Krishnavani, N. Manimaran and B. Shamaladevi, Port. Electrochim. Acta, 2014, 29, 429.

35. R. Vera, R. Schrebler, P. Cury, R. Del Rio and H. Romero, J. Appl. Elecrochem., 2007, 37, 519 . 